\title{
Effectiveness of Endophytic Bacterial Consortium of Coffee Plant on Mortality of Pratylenchus Coffeae in Vitro
}

\author{
Dwi Halimah ${ }^{1)}$, Abdul Munif ${ }^{* *}$, and Giyanto ${ }^{1)}$ \\ ${ }^{1)}$ Inspectorate General, Ministry of Agriculture, Jl. Harsono RM No. 3 Ragunan, Jakarta \\ ${ }^{2}$ Crop Protection Department, Bogor Agricultural University, Darmaga Bogor 16680 \\ ${ }^{*}$ Corresponding author: munif73@gmail.com \\ Received: 30 July 2015 / accepted: 05 October 2015
}

\begin{abstract}
Bacteria live in wild in form of a consortium. Use of microbial consortium tends to give better results than single isolate, because the action of enzyme of each type of microbe can complement each other in order to survive. This study aimed to study the effectiveness of bacterial endophytic consortium from coffee plant on plant growth and mortality of parasitic nematodes in coffee. Isolation of bacteria is conducted by growing the crushed roots, stems and leaves of coffee on $20 \%$ TSA media, then testing their hemolysis and hypersensitivity reaction. Selected isolates were tested on their effect on the growth of seedling and Pratylenchus coffeae mortality, as well as their chitinolytic, proteolytic, lipolytic, HCN production, dissolution of phosphate $(\mathrm{P})$ and fixation of nitrogen $\left(\mathrm{N}_{2}\right)$ abilities. The results showed that from 27 isolates of the consortium, 23 isolates showed negative reaction to hypersensitive test and 9 isolates to hemolysis test. The highest mortality rate was shown by K6 isolate $(65.8 \%)$. The highest growth was shown by $\mathrm{K} 15$ and $\mathrm{K} 21$ isolates while the highest root length by $\mathrm{K} 21$ isolate. Further analisys showed that $100 \%$ of the isolates could hydrolyze proteases, lipid, and produce $\mathrm{HCN}$, while chitinolytic activity was shown by $78 \%$ isolates which could fix $\mathrm{N}_{2}$ and $11 \%$ of isolates could dissolve phosphate.
\end{abstract}

Keywords: endophytic bacteria consortium, Pratylenchus coffeae, hydrolysis enzyme, growth promoters

\section{INTRODUCTION}

Pratylenchus coffeae nematodes is the most harmful nematodes on coffee plantations, both on Arabica coffee and Robusta coffee. $P$. coffeae is classified as endoparasitic sedentary or sedentary endoparasites (migratory). Female nematodes lay eggs in the root cortex tissue, especially young root tissue and eventualy damage the roots. Root damage will be more widespread with the growing population of nematodes, and finally the nematodes will move out of the roots and look for other healthy roots (CABI, 2015).

$P$. coffeae attack on Robusta coffee and may cause a decrease in production up to $57 \%$.
$R$. similis attack together with $P$. coffeae on Arabica coffee and can result in more severe damage reached to $80 \%$ and the plant will die at the age of less than three years (Wiyadiputra, 1998). This is due to that $P$. coffeae lives in the area of soil depth of $30 \mathrm{~cm}$ while $R$. similis at a depth of $50 \mathrm{~cm}$ (Hulupi \& Mulyadi, 2007). According to Wiryadiputra \& Atmawinata (1998), the decline in production by $P$. coffea on Robusta coffee ranged from 28.7 to $78.4 \%$. Until the age of five years, the plant mortality rate can reach $30 \%$ of the population of coffee plantations in certain farms (Nursol et al., 2006). P. coffeae distribution in Indonesia is quite extensive, including all main coffee producing areas (Wiryadiputra \& Atmawinata, 1998). 
Nematode control has been carried out with technical culture (use of nematode free planting materials), nematicides, resistant varieties (CABI, 2015), coffee replanting after 5 years period of fallow (Trinh, 2011) and biological agent using endophytic bacteria (Vega et al., 2005; Harni \& Khaerati, 2013).

Endophyte is a micro organism that live inside plant tissues which provide a neutral, beneficial or detrimental effecs (Sikora et al., 2007). Use of endophytic bacteria as biological control has been studied in many plants, including coffee plants. Harni \& Khaerati (2013) found that from 442 isolates, $12.3 \%$ were antagonistic and $14.2 \%$ can stimulate plant growth. In addition, 3 obtained isolates were potentially suppress population of $P$. coffeae with mortality about $94.8 \%$. Vega et al. (2005) have isolated Bacillus, Burkholderia, Clavibacter, Curtobacterium, Escherichia, Micrococcus, Pantoea, Pseudomonas, Serratia, and Stenotrophomonas from fruits, leaves and stems of coffee.

The previous research on the ability of endophytic bacteria as biocontrol agents as described above, was the result of exploration in form of single isolate. According to Baker \& Cook (1974), microbes in nature, live in a niche or the same niche, as a group of endophytic bacteria in form of a consortium, to create biological buffer area which supports biological balance, resulting in stable relationship and mutual benefit and ecosystem balance. Munif et al. (2015) had isolated and tested the potential of consortium of endophytic bacteria, from a forest, plant as biocontrol agents and plant growth promoters of tomatoes. The exploration of endophytic bacterial consortium from coffee plant and their potential as growth promoton and biological agents has not been carried out. Therefore, the aim of this research was to explore and use of endophytic bacterial consortium to suppress nematode on coffee.

\section{MATERIALS AND METHODS}

Samples of plant roots infected by $P$. coffeae parasitic nematode, were obtained from a multiplication carried out in Indonesian Coffee and Cocoa Research Institute, Jember. Two months old coffee seedlings were inoculated with $P$. coffeae as many as 50 nematodes/plant which was later used as source of nematodes for inoculation.

$P$. coffeae nematodes were extracted from nematode infected roots with mist chamber method. Infected roots were cut about $1-2 \mathrm{~cm}$ and placed in a funnel covered with a filter cloth. Under the funnel a nematode reservoir container was placed connected with sprayer. The funnel filled with roots was put in a mist chamber equipped with a nozzle which produced water mist continuously. Harvesting performance of nematodes took 2-3 days after nebulization in a mist chamber. Harvesting was done by taking the solution in the container and filtered with a 500 mesh sieve. The nematodes were then counted as required.

\section{Isolation of Endophytic Bacterial}

Isolation of a consortium endophytic bacteria was conducted following the modified method of Hallmann et al. (1997). Samples of the coffee plants in form of roots, stems and leaves were washed with water and weighed as mach as one $\mathrm{g}$ fresh. Sterilization of tissue surface by soaking in $70 \%$ alcohol for 2 minutes, followed by immersion in $\mathrm{NaOCl} 3 \%+3$ drops of Tween 20 for 4 minutes, and rinsed with sterile distilled water three times. The samples were then crushed using a sterile mortar until fine size and diluted up to $10^{-3}$. Suspension of $10^{-2}$ dilution was grown on TSA $20 \%$ and incubated for 24 hours at room temperature. As a comparison, or control, is conducted an etching at the roots, stems and leaves were 
that has been surface sterilized (before the ground) on the TSA media $20 \%$. If in the control there was no growth of bacteria then the bacterial colony was assumed as a result of endophytic isolation.

Harvesting bacterial endophytic consortium from each source (roots, stems and leaves) was done by pouring $2 \mathrm{~mL}$ of TSB medium $100 \%+$ glycerol $20 \%$ on a petri dish. The colonies were isolated from solid medium using a sterile ose needle. The suspension of consortium endophytic bacteria was then stored in $1.5 \mathrm{~mL}$ Eppendorf tube at $4^{\circ} \mathrm{C}$.

\section{Hypersensitivity and Hemolysis Tests}

Hypersensitivity test of the endophytic bacterial consortium was conducted to determine its pathogenicity using a healthy tobacco plant. The endophytic bacterial consortium was propagated in TSB medium $100 \%$, incubated in a shaker with the speed of $100 \mathrm{rpm}$ for 24 hours. Suspension of bacterial endophytic consortium was injected using a syringe on tobacco leaves each $2 \mathrm{~mL}$ with three replicates for each endophytic bacteria, then incubated for 24 hours to 48 hours and observed the occurrence of chlorosis/ necrosis on the leaves. The bacterial consortium which showed a negative reaction (no necrosis) was used for further testing.

Consortium of endophytic bacteria that showed a negative reaction to the hypersensitive, was tested for its ability to hydrolyze red blood cell. The 24 hours old culture of consortium bacteria was grown at Blood Agar media, then incubated for 24 hours and observed for its clear zone formation.

\section{Plant Growth Promoting Test}

Selection of endophytic bacterial consortium as a plant growth promotor was carried out by modified method of Harni \& Khaerati (2013). Hot water was applied on tomato seeds (as control). Tomato seeds were soaked in sterile distilled water at a temperature of about $55^{\circ} \mathrm{C}$ for 20 minutes, followed by immersion in a suspension of endophytic bacteria consortium for approximately one hour, then drained on sterile tissue paper. Further, the seeds were planted on moistened sterile filter paper and stored in a closed sterile tray. As a control, the tomato seeds were soaked with sterile water and planted on the same medium. Observations carried out 4 days after planting.

\section{Nematodes Mortality Test}

The ability of endophytic bacterial consortium in inhibiting $P$. coffeae was carried out by following the modified method of Harni \& Khaerati (2013). Nematode test inoculum was prepared by following the procedure of nematode preparation for in vitro endophytic test. Endophytic bacterial consortium was propagated by growing a $100 \mathrm{~mL}$ of culture in $100 \mathrm{~mL}$ TSB medium and shaked with speed $100 \mathrm{rpm}$ for 24 hours. Secondary metabolites produced by the endophytic consortium bacteria was obtained by centrifugating at a speed of $6500 \mathrm{rpm}$, the supernatant was filtered with milipore $0.25 \mathrm{~mm}$ diameter and pore size of $0.2 \mu \mathrm{m}$. The filtrate was used to test the ability of the endophytic bacterial consortium on nematodes mortality. Fifty parasitic nematodes were put in $5 \mathrm{~mL}$ of secondary metabolites placed in a petri dish, stored at room temperature and observed after 24 hours. Each treatment was repeated three times.

\section{Chitinolytic activity}

Chitinolytic test was conducted following the modified method of Marin et al. (2013). Consortium of bacterial isolates were multiplied 
in trypsic soybean broth (TSB) media and shaken for 24 hours at a speed of $100 \mathrm{rpm}$. Sterile filter paper diameter of $0.5 \mathrm{~cm}$ was placed on a nutrient agar medium (NA) enriched by $0.4 \%$ colloidal chitin in a petridish. A total $4 \mu \mathrm{L}$ of culture was inoculated on the filter paper. Cultures were incubated at room temperature for 72-96 hours. Chitinolytic activity was measured based on diameter of clear zone that is formed.

\section{Enzymes activities}

Protease activity test was carried out by the modified procedure of Denizci et al. (2004). Liquid culture isolates were inoculated onto sterile paper blank disc that had been placed on the skim milk agar media (SMA), with a composition of $900 \mathrm{~mL}$ of $100 \%$ trypsic soy agar media (TSA) sterile plus 100 $\mathrm{mL}$ of sterile skim milk concentration of $10 \%$. Incubation was done at room temperature for 24-72 hours. Proteolytic activity was shown by the formation of a clear zone surrounding the bacterial colonies (Baehaki \& Budiman, 2011).

Lipolytic test used rhodamine-B mediaagar with $20 \mathrm{~mL}$ of liquid medium Hass Bushnell, $0.6 \mathrm{~mL}$ (3\%) of cooking oil and $0.04 \mathrm{~mL}$ rhodamine-B $0.1 \%$ in water. Further, the isolates were streaked onto medium and incubated at room temperature for 48 hours. Lipolytic activity was characterized by the appearance of reddish orange luminescence zone under UV light.

Phosphatase test was carried out following the modified method of Gupta et al. (2012). Consortium isolates were inoculated on sterile paper disc in selective media Pikovskaya and observed for 48 hours at $30^{\circ} \mathrm{C}$. The ability of bacteria live in the phosphate solvent in media was characterized by the formation of a clear zone around the bacteria colony.

\section{$\mathrm{N}_{2}$ fixation and $\mathrm{HCN}$ production}

$\mathrm{N}$ fixation ability was tested by growing isolates as much as $1 \mathrm{~mL}$ in semi-solid NFB (Nitrogen Fixing Bacteria) in $10 \mathrm{~mL}$ medium (Yim et al., 2009). Incubation was performed 4-7 days until the color changes from greenish blue media, as well as emerging pellicle/ring bacteria in media.

Production of cyanide was tested following the modified procedures of Wei et al. (1991). Bacterial culture medium was $100 \%$ nutrient agar (NA) containing $4.4 \mathrm{~g}$ glysin. Cyanide production was detected using cyanide detection solution (CDS), which consisted of $200 \mathrm{~mL}$ of sterile distilled water containing $2 \mathrm{~g}$ of picric acid and $8 \mathrm{~g}$ of sodium carbonate. Filter paper was cut to a size of $1 \mathrm{~cm} \mathrm{x} 1 \mathrm{~cm}$ and sterilized. Bacterial consortium isolates was streaked in quadrant on NA media enriched with glysin. On the petri dish lid, a sterile filter paper was placed and soaked in a solvent of CDS and dried. Observation was made on day 4 after inoculation. $\mathrm{HCN}$ production was characterized by color changing of the filter paper from bright yellow to red orange.

\section{RESULTS AND DISCUSSION}

Isolation of endophytic bacteria consortium from coffee plants obtained 27 isolates, where 9 isolates from leaves, 9 isolates from roots, and 9 isolates from stem. Isolates were selected to obtain potential ones as biological agents. One absolute requirement of a bacterium can be used as a biological agent is that the microbe is not a potential pathogen or pathogens to plants. Baker \& Cook (1974) stated that antibiotics (secondary metabolites) produced by an antagonist agent may not cause damage to host. Hypersensitivity test is conducted to collect isolates that are non pathogenic. As a result, from 27 isolates, 
23 non pathogenic isolates were obtained (Table 1, Figure 1).

Further, a microbe can be grouped as an antagonist agent if it is not pathogenic to human, therefore hemolysis test was conducted. Hemolysis is a destruction process of human erythrocytes (Segel, 2011). Hemolysin enzyme may cause lysis of erythrocytes, that are produced by several pathogenic bacteria, which is gram-negative bacteria such a Escherichia coli, Pseudomonas aeroginosa, Serratia spp., Proteus spp. and gram-positive such as Streptococcus spp., Staphylococcus aureus, Listeria spp. (Bauman, 2007). The results showed that there were 9 isolates that are gamma hemolysis, namely K6, K7, K8, K10, K12, K15, K19, K20, and 21 (Table 1, Figure 2)

Nine selected isolates were tested for their ability on the mortality of $P$. coffeae in vitro. The high mortality percentages were shown by K6, K15 and K8 isolates in the range of $43-66 \%$ (Table 3 ). These results are in line with Harni \& Khaerati (2013) that $12.3 \%$ single endophytic bacteria isolates tested was able to kill 5-80\% P. coffeae.

The best shoot growth of tomato was shown by K21, K15 and K8 isolates followed, while for root length was shown by K21 followed with $\mathrm{K} 8$ and $\mathrm{K} 10$ isolates. The isolates were also significantly different with controls (Table 3). According to Sutariati et al. (2006), seed treatment with biological agents can improve seed germination and seedling growth of chili.

The ability of endophytic bacteria to increase the mortality of nematodes was higher than the ability of increasing the tomato shoot growth. Mechanism of endophytic bacteria in suppressing nematodes and plant growth can increase through antibiosis and induced resistance to promote plant growth. This is shown by the ability of the consortium to produce proteolytic, chitinolytic, and lipolytic enzymes, HCN production, dissolving phosphate and fixing N (Table $4 \&$ Figure 3).

Jalgaonwala \& Mahajan (2011) mentioned that almost all of endophytic microorganism are able to perform enzymatic activity. The enzymatic activity of all tested isolates were proteolytic amylolytic, cellulolytic, esterolitik, lipolytic and asparaginase, further, that endophytic bacteria had enzymatic activity larger than the endophytic fungi.

The results showed that $100 \%$ of isolates could hydrolyze proteins (proteolysis), fat (lipolytic), and produce HCN. Chitinolytic activity was show by $78 \%$ isolates meanwhile $67 \%$ isolates could fix $\mathrm{N}_{2}$ and $11.1 \%$ of isolates could dissolve phosphates. Three
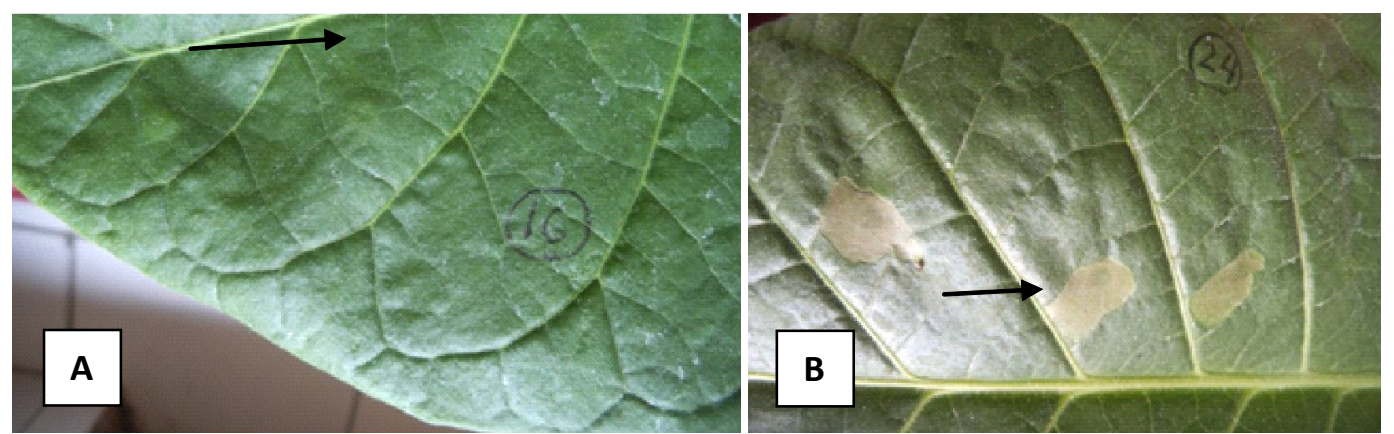

Figure 1. Hypersensitive reaction; negative/nonpathogen (A) and positive/pathogen (B) 
Halimah et al.

Table 1. The origin of isolates consortium endophytic bacteria, hipersensitiv reaction/HR and hemolysis test

\begin{tabular}{|c|c|c|c|c|c|c|}
\hline Location & Clone & $\begin{array}{l}\text { Number of } \\
\text { sample }\end{array}$ & Isolate code & Tissue & HR & Hemolysis \\
\hline \multirow[t]{9}{*}{ West Java } & BP 939 & 1 & K1 & Root & + & + \\
\hline & & & $\mathrm{K} 2$ & Shoot & + & + \\
\hline & & & $\mathrm{K} 3$ & Leaves & + & + \\
\hline & & 2 & K4 & Root & + & + \\
\hline & & & K5 & Shoot & + & + \\
\hline & & & K6 & Leaves & - & - \\
\hline & & 3 & $\mathrm{~K} 7$ & Root & - & - \\
\hline & & & K8 & Shoot & - & - \\
\hline & & & K9 & Leaves & + & + \\
\hline \multirow[t]{9}{*}{ East Java } & BР 939 & 1 & K10 & Root & - & - \\
\hline & & & K11 & Shoot & + & + \\
\hline & & & $\mathrm{K} 12$ & Leaves & - & - \\
\hline & & 2 & K13 & Root & + & + \\
\hline & & & K14 & Shoot & + & + \\
\hline & & & K15 & Leaves & - & - \\
\hline & & 3 & K16 & Root & + & + \\
\hline & & & K17 & Shoot & + & + \\
\hline & & & K18 & Leaves & + & + \\
\hline \multirow[t]{9}{*}{ West Java } & BP 308 & 1 & K19 & Root & - & - \\
\hline & & & $\mathrm{K} 20$ & Shoot & - & - \\
\hline & & & $\mathrm{K} 21$ & Leaves & - & - \\
\hline & & 2 & K22 & Root & + & + \\
\hline & & & K23 & Shoot & + & + \\
\hline & & & $\mathrm{K} 24$ & Leaves & + & + \\
\hline & & 3 & $\mathrm{~K} 25$ & Root & + & + \\
\hline & & & K26 & Shoot & + & + \\
\hline & & & K27 & Leaves & + & + \\
\hline Control + & & & & & + & + \\
\hline
\end{tabular}

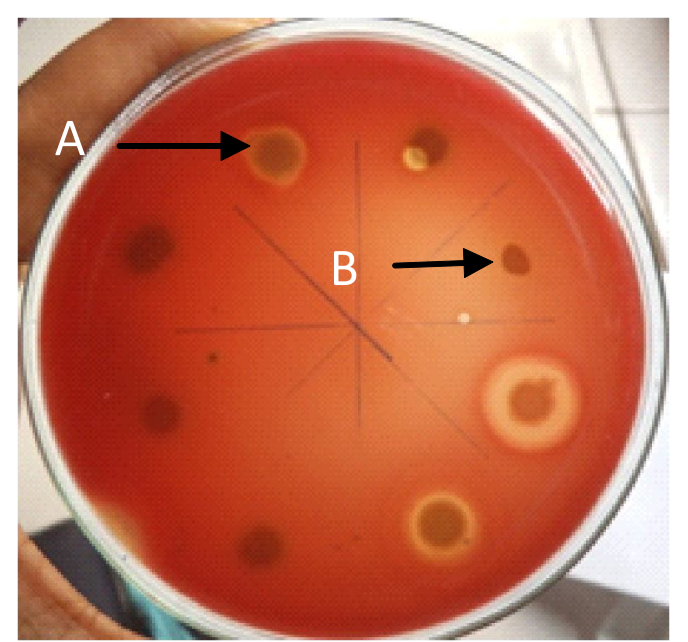

Figure 2. Positive hemolysis (A); Negative hemolysis (B) 
Effectiveness of endophytic bacterial consortium of coffee plant on Pratylenchus coffeae mortality in vitro

Table 2. Effect of endophytic bacteria conssortium on shoot and root growth of tomatos

\begin{tabular}{|c|c|c|}
\hline \multirow{2}{*}{ Isolate } & \multicolumn{2}{|c|}{ Growth } \\
\hline & Shoot, $\mathrm{cm}$ & Root, $\mathrm{cm}$ \\
\hline K6 & $2,20^{\mathrm{b}}$ & $1,58^{d}$ \\
\hline K7 & $3,10^{a b}$ & $2,39 \mathrm{dc}$ \\
\hline K8 & $3,40^{\mathrm{a}}$ & $4,55^{\mathrm{ab}}$ \\
\hline K10 & $3,20^{a b}$ & $4,36^{\mathrm{ab}}$ \\
\hline K12 & $2,70^{a b}$ & 3,88 abc \\
\hline K15 & $3,60^{\text {a }}$ & $372 a b c$ \\
\hline K19 & $2,30^{\mathrm{b}}$ & $3,01 \mathrm{bdc}$ \\
\hline K20 & $2,90 \mathrm{ab}$ & $3,59 a b c$ \\
\hline K21 & $3,60^{\text {a }}$ & $5,13^{a}$ \\
\hline Media/medium & - & - \\
\hline Kontrol/control & $2,70^{\mathrm{ab}}$ & $4,6^{\mathrm{ab}}$ \\
\hline
\end{tabular}

Note: Means in the same column followed by the same letter are not significantly different according to Duncan Test with $\alpha=5 \%$.

Table 3. Effect of endophytic bacteria consortium to mortality of $P$. coffeae

\begin{tabular}{|c|c|c|c|c|}
\hline Isolate & $\Sigma$ live nematode* & $\Sigma$ killed nematode* & Total* & Mortality, $\% *$ \\
\hline K6 & 30,33 & 16,67 & 47,00 & $65,80 \mathrm{a}$ \\
\hline K7 & 9,00 & 44,00 & 53,00 & $16,67 \mathrm{bdc}$ \\
\hline K8 & 21,67 & 28,33 & 50,00 & $43,13 \mathrm{ab}$ \\
\hline $\mathrm{K} 10$ & 10,67 & 39,33 & 50,00 & $21,21 \mathrm{abc}$ \\
\hline K12 & 15,00 & 32,67 & 47,67 & $33,04 \mathrm{abc}$ \\
\hline $\mathrm{K} 15$ & 22,67 & 29,67 & 52,33 & $43,28 \mathrm{ab}$ \\
\hline K19 & 19,33 & 28,67 & 48,00 & $40,26 \mathrm{ab}$ \\
\hline K20 & 21,00 & 28,33 & 49,33 & $42,58 \mathrm{ab}$ \\
\hline K21 & 16,67 & 25,67 & 42,33 & $37,64 \mathrm{ab}$ \\
\hline Negative control & 0,00 & 55,33 & 55,33 & $0,00 \mathrm{~d}$ \\
\hline Medium & 2,67 & 47,67 & 50,33 & $5,23 \mathrm{dc}$ \\
\hline
\end{tabular}

Note: K: consortium, ${ }^{*}$ the value is average from 3 times of treatments; Means in the same column followed by with the same letter are not significantly different according to Duncan Test with $\alpha=5 \%$.

Table 4. Antibiosis mechanism and induce resistance test

\begin{tabular}{|c|c|c|c|c|c|c|}
\hline Isolate & $\begin{array}{l}\text { Proteolytic } \\
(\mathrm{mm})\end{array}$ & $\begin{array}{l}\text { Chitinolytic } \\
(\mathrm{mm})\end{array}$ & Lipolytic & $\mathrm{HCN}$ & $\begin{array}{l}\text { P. solubilization } \\
(\mathrm{mm})\end{array}$ & $\mathrm{N}_{2}$-Fixing \\
\hline K6 & $1.05^{\mathrm{b}}$ & $3.25 \mathrm{c}$ & + & + & $0.00^{b}$ & + \\
\hline K7 & $1.00^{\mathrm{b}}$ & $2.80 \mathrm{c}$ & + & + & $0.00^{\mathrm{b}}$ & - \\
\hline K8 & $1.93^{\mathrm{b}}$ & $2.55 \mathrm{c}$ & + & + & $0.00^{\mathrm{b}}$ & + \\
\hline K10 & $4.50^{\mathrm{ab}}$ & 1.73 & + & + & $0.00^{\mathrm{b}}$ & + \\
\hline K12 & $5.13^{\mathrm{b}}$ & $5.13 \mathrm{a}$ & + & + & $0.00^{\mathrm{b}}$ & + \\
\hline K15 & $2.60^{\mathrm{b}}$ & $2.66 \mathrm{c}$ & + & + & $7.58^{\mathrm{a}}$ & + \\
\hline K19 & $7.00^{\mathrm{a}}$ & 0.00 & + & + & $0.00^{\mathrm{b}}$ & - \\
\hline $\mathrm{K} 20$ & $2.30^{\mathrm{b}}$ & $4.00 \mathrm{~b}$ & + & + & $0.00^{\mathrm{b}}$ & + \\
\hline $\mathrm{K} 21$ & $3.00^{\mathrm{b}}$ & 0.00 & + & + & $0.00^{\mathrm{b}}$ & - \\
\hline
\end{tabular}

Note: Means in the same column followed by the same letter are not significantly different according to Duncan Test with $\alpha=5 \%$. 


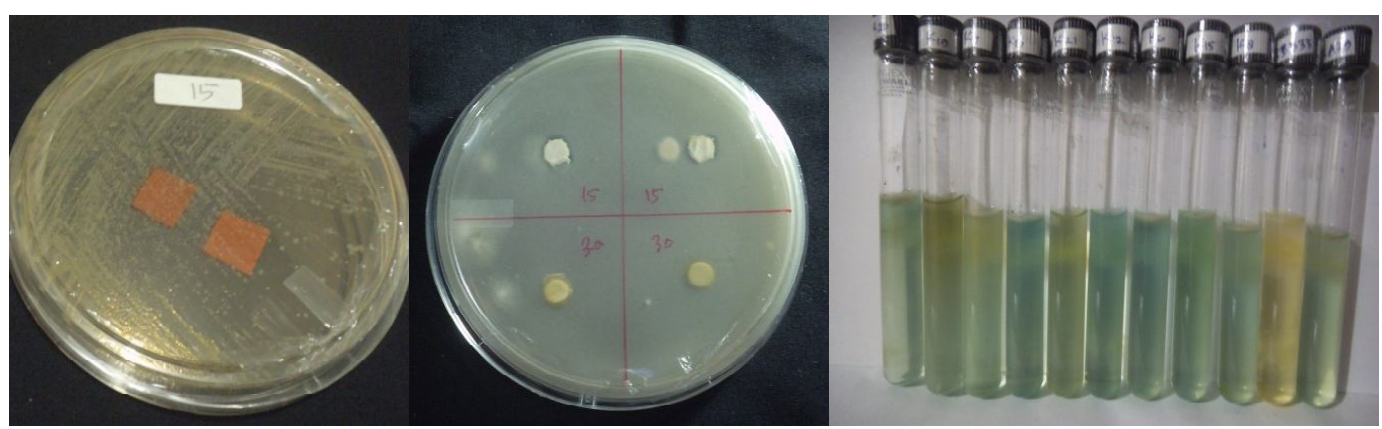

Gambar 3. Mechanism test of endophytic bacteria concortium controlling $P$. coffeae nematode, A: positive chitinolysis, B: positive proteolysis, C: positive lipolysis/orange colour of colony under UV light, D: positive produce HCN, E: positively dissolution of phosphate/holozone formed around the colony, F: positivelly fixation of nitrogen/change of medium colour from green to blue.

isolates (K6, K8, and $\mathrm{K} 15)$ that showed the high mortality showed a positive reaction to the antibiosis mechanism test, meanwhile $\mathrm{K} 6$ and $\mathrm{K} 8$ isolates reacted negatively to the $\mathrm{P}$ dissolution test (Table 4). This study showed that an endophytic bacteria can control plant pathogens via several mechanisms, including antibiosis and promoting plant growth. Jain et al. (2012) mentioned that a consortium of microbes in the rhizosphere can mediate induced systemic resistance (ISR). Chitinolytic and proteolytic bacteria has been widely reported to inhibit the development of pathogenic Bacillus spp. (Bressan \& Figueiredo, 2010), Streptomyces tendae (Abdulkhair, 2012), Bacillus cereus QQ308 (Chang et al., 2006). Chitinolytic and proteolytic activity of endophytic bacteria also play a role in antibiosis against nematodes $P$. brachyurus (Harni et al., 2007). Carrim et al. (2006) reported that the endophytic bacteria isolated from Jacaranda decurrens Cham showed proteolytic (60\%) and lipolytic (60\%) activities. Proteolytic activity by endophytic bacteria can stimulate immune system of plants.

Bertham \& Nusantara (2011) stated that interactions with $\mathrm{P}$ inorganic cations $(\mathrm{Fe}$, $\mathrm{Al}$, and $\mathrm{Ca}$ ) and immobilization into an organic compound by microorganisms cause low availability of $\mathrm{P}$ in the soil. Applications of
Pseudomonas synxantha, Burkholderia gladioli, Enterobacter hormaechei and Serratia marcescens bacteria that are phosphate solubilizers can increase the availability of phosphate in soil, the absorption of phosphate in plants and plant growth and Aloe production up to $673 \%$ (Gupta et al., 2012). Bacteria of the genus Azotobacter, Bacillus, Micrococcus, Pseudomonas, Staphylococcus, Acetobacter, Escherichia, Flavobacterium, and Paracoccus are main phosphate solubilizers (Marista et al., 2013; Trivedi et al., 2007). Nitrogen is a macronutrient that plants need in large amount, so that $\mathrm{N}_{2}$ fixation by endophytic bacteria provide more benefits because of endophytic bacteria located in the plant tissue, so the results of $\mathrm{N}_{2}$ fixation are not easily separated. Adriano-Anaya et al. (2011) reported that the application of free-living $\mathrm{N}_{2}$-fixing bacteria can suppress nematode populations and Radopholus similis attack symptoms.

All consortium isolates test could produce HCN in glycine media. Heydaril et al. (2011) found that $37 \%$ of the tested fluorescent Pseudomonas bacteria were capable of producing hydrogen cyanide gas. Pseudomonas bacteria normally can produce secondary metabolites such as cyanide wich attack $P$. coffeae through respiratory disorder. 
Gallangher \& Manoil (2001) found that secondary metabolites such as hydrogen cyanide was a major toxin produced by $P$. aeruginosa and kill Caenorhabditis elegans, a cosmopolitan soil nematode.

The consortium endophytic bacteria showed high ability in phosphate dissolution, promoting growth and $\mathrm{N}_{2}$ fixation (Gupta et al., 2012; Suriaman, 2010). It is thought to be caused by a type of bacteria that are more variable in the consortium than single isolate, allowing colonization was faster in rhizosphere root and dominated the root. Sarma et al. (2015) in his review mentioned that biocontrol mechanisms are diverse from each bacteria in a consortium also can increase the suppression of plant diseases.

\section{CONCLUSION}

Consortium of endophytic bacteria can control $P$. coffeae nematodes through antibiosis mechanism of proteolytic, lipolytic, HCN production and chitinolytic, and the mechanism of induction of resistance by promoting growth through $\mathrm{N}$ fixation and phosphate dissolution. Consortium of endophytic bacteria is more profitable than a single isolate because of its kind that is more varied, so the ability to colonization and dominance rhizosphere and root is more quickly, as well as the mechanism of action of biocontrol agents are more variedcan improve the suppression of disease.

\section{ACKNOWLEDGEMENT}

Thanks to Agency of Agriculture Human Resource Development (BPSDMP) for part of the research fund, to Jakarta Assessment Institute for Agricultural Technology (BPTP) for research facility and to Indonesian Coffee and Cocoa Research Institute for multiplication of nematodes.

\section{REFFERENCES}

Abdulkhair, W.M. (2012). Chitinolytic activity of highly halotolerant Streptomyces tendae against Fusarium oxysporum PTK2. African Journal of Biotechnology, 11, 15523-15532.

Adriano-Anaya, M.L.; F.A. Guttierrez-Miceli; L. Dendooven \& M. Salvador-Figueroa (2011). Biofertilization of banana (Musa spp. L.) with free-living $\mathrm{N}_{2}$ fixing bacteria and their effect on mycorrhization and the nematode Radopholus similis. Journal of Agricultural Biotechnology Sustainable and Development, 3, 1-6.

Baker, K.F. \& R.J. Cook (1974). Biological Control of Plant Pathogens. W.H. Freeman \& Company. San Fransisco.

Baehaki, A. \& A. Budiman (2011). Isolasi dan karakterisasi protease dari bakteri tanah rawa Indralaya, Sumatera Selatan. Jurnal Teknologi dan Industri Pangan, 22, 37-42.

Bauman, R. (2007). Innate immunity. p. 437-57. In: Bauman, R. (Ed.). Microbiology with Diseases by Taxonomy. Edt- $2^{\text {nd }}$. Pearson (Ed.). Publ. New York.

Bertham, R.Y.H. \& A.D. Nusantara (2011). Mekanisme adaptasi genotipe baru kedelai dalam mendapatkan hara fosfor dari tanah mineral masam. Jurnal Agronomi Indonesia, 39, 24-30.

Bressan, W. \& J.E.F. Figueiredo (2010). Chitinolytic Bacillus spp. antagonistic to Fusarium moniliforme in maize. Journal of Plant Pathology, 92, 343-347.

CABI (2015). Pratylenchus coffeae. CABI, Malaysia.

Carrim, A.J.I.; E.C. Barbosa \& J.D.G. Vieira (2006). Enzymatic activity of endophytic bacterial isolates of Jacaranda decurrens Cham. (Carobinha-docampo). Brazilian Archives of Biology and Technology, 49, 353-359.

Chang, W.T.; Y.C. Chen \& C.L. Jao (2007). Antifungal activity and enhancement of plant growth by Bacillus cereus grown 
on shellfish chitin wastes. Bioresource Technology, 98, 1224-1230.

Gallangher \& Manoil (2001). Pseudomonas aeruginosa PAO1 kills Caenorhabditis elegans by cyanide poisoning. Journal of Bacteriology, 183, 6207-6214.

Gupta, M.; S. Kiran; A. Gulati; B. Singh \& R. Tewari (2012). Isolation and identification of phosphate solubilizing bacteria able to enhance the growth and aloin-A biosynthesis of Aloe barbadensis Miller. Microbiological Research, 167, 358-363.

Hallmann, J.; A. Quadt-Hallmann; W.F. Mahafee \& J.W. Kloepper (1997). Bacterial endophytes in agricultural crops. Canadian Journal of Microbiology, 43, 895-914.

Harni, R.; A. Munif; Supramana \& I. Mustika. (2007). Potensi bakteri endofit pengendali nematoda peluka akar (Pratylenchus brachyurus) pada nilam. Journal of Biosciences, 4, 7-12.

Harni, R. \& Khaerati (2013). Evaluasi bakteri endofit untuk pengendalian nematoda Pratylenchus coffeae pada tanaman kopi. Buletin Ristri, 4, 109-116.

Heydaril, S.; P.R. Meghadam \& S.M. Arab. (2011). Hydrogen cyanide production ability by Pseudomonas fluorescence bacteria and their inhibition potential on weed germination. Proceeding of Competition for Resources in Changing World: New Drive to Rural Development. 7-9 Oktober 2008, Tropentag, Hohenheim, Germany.

Hulupi, R. \& Mulyadi (2007). Sebaran populasi nematoda Radopholus similis dan Pratylenchus coffeae pada lahan perkebunan kopi. Pelita Perkebunan, 23, 176-182.

Jain, A.; S. Singh; B.K. Sarma \& H.B. Singh (2012). Microbial consortium-mediated reprogramming of defence network in pea to enhance tolerance against Sclerotinia sclerotiorum. Journal of Applied Microbiology, 112, 537-550.
Jalgaonwala, R. \& R. Mahajan (2011). Evaluation of hydrolytic enzyme activities of endophytes from some indigenous medicinal plants. Journal of Agricultural Technology, 7, 1733-1741.

Marin, M.; I. Wong; J. Mena; R. Moran; E. Pimentel; I. Sanchez; R. Basulto \& A. Moreira (2013). Zea mays L. plant growth promotion by Tsukamurella paurometabola strain C-924. Biotecnología Aplicada, 30, 105-110.

Marista, E.; S. Khotimah \& R. Linda (2013). Bakteri pelarut fosfat hasil isolasi dari tiga jenis tanah rizosfer tanaman pisang nipah (Musa paradisiaca var. nipah) di kota Singkawang. Jurnal Protobiont, 2, 93-101.

Munif, A.; A.P. Pradana, B.P.W. Soekarno \& E.N. Herliyana (2015). Isolasi dan uji potensi konsorsium bakteri endofit asal tanaman kehutanan sebagai agens biokontrol dan pemacu pertumbuhan tanaman tomat. Prosiding Seminar Nasional Perlindungan Tanaman. Bogor, Indonesia. 198-206.

Nursol, M.; Syahnen \& I. Roma TUS (2006). Pengaruh Pemberian Kompos dan Ekstrak Daun Nimba, Pinang Muda dan Tembakau Terhadap Perkembangan Nematoda Akar Kopi. Balai Pengembangan Proteksi Tanaman Perkebunan (BP2TP) Sumatera Utara, Medan.

Sarma, B.K.; S.K. Yadav; S. Singh \& H.B. Singh (2015). Microbial consortium-mediated plant defense against phytopathogens: Readdressing for enhancing efficacy. Soil Biology \& Biochemistry, 30, 1-9.

Segel, G.B. (2011). Hemolytic anemia. p. 1659-1682. In: R.M. Kliegman; B.F. Stanton; N.F. Schor; J.W. Geme; R.F. Behrman (Eds.). Nelson Text Book of Pediatrics. Edt-19 ${ }^{\text {th }}$. Saunders, Philadelphia.

Sikora, R.A.; K. Schäfer \& A.A. Dababat (2007). Mode of action associated with microbially induced in planta suppression of plant-parasitic nematodes. 
Australasian Plant Pathology, 36, 124-134.

Suriaman, E. (2010). Potensi Bakteri Endofit dari Akar Tanaman Kentang (Solanum tuberosum) dalam Memfiksasi $\mathrm{N}_{2}$ dari Udara dan Menghasilkan Hormon IAA (Indol Acetid Acid) Secara In Vitro. Skripsi. Universitas Islam Negeri Malang. Malang.

Sutariati, G.A.K.; Widodo; Sudarsono \& S. Ilyas (2006). Pengaruh perlakuan rizobakteri pemacu pertumbuhan tanaman terhadap viabilitas benih serta pertumbuhan bibit cabai. Buletin Agronomi, 34, 46-54.

Trinh, P.Q.; W.M.L Wesemael; C.N. Nguyen, \& M. Moens (2011). Decline of Pratylenchus coffeae and Radopholus arabocoffeae populations after death and removal of 5 -year-old arabica coffee (Coffea arabica $\mathrm{cv}$. Catimor) trees. Nematology, 13, 49-500.

Trivedi, P.; B. Kumar; A. Pandey \& L.M.S. Palni (2007). Growth promotion of rice by phosphate solubilizing bioinoculants in a Himalayan location. Development in Plant Soil Science, 102, 291-299.
Vega, F.E.; M. Pava-Ripoll; F. Posada \& JS. Buyer (2005). Endophytic bacteria in Coffea arabica L. Journal of Basic Microbiology, 45, 371-380.

Wei, G.; J.W. Kloepper \& S. Tuzun (1991). Induction of systemic resistance of cucumber to Colletotrichum orbicularae by select of plant growth promoting rhizobacteria. Phytopathology, 81, 1508-1512.

Wiryadiputra, S. \& O. Atmawinata (1998). Kopi (Coffea spp.) p. 53-59. In: Pedoman Pengendalian Hama Terpadu Tanaman Perkebunan. Puslitbang Tanaman Industri Badan Litbang Pertanian. Deptan.

Yim, W-J.; S. Poonguzhali; M. Madhaiyan; P. Palaniappan; M. Siddikee \& T. Sa (2009). Characterization of plant-growth promoting diazotrophic bacteria isolated from field grown Chinese cabbage under different fertilization conditions. The Journal of Microbiology. 47, $147-155$.

$* * 0 * *$ 